\title{
The Effect of Family History of Diabetes and Middle Eastern Background on Abdominal Obesity is Modified by Gender: A Population based Cross-Sectional Study
}

\author{
Faiza Siddiquii ${ }^{1}$, Helena Isberg ${ }^{1}$, Charlotte A Larsson ${ }^{2}$ and Louise Bennet ${ }^{1,3 *}$ \\ ${ }^{1}$ Department of Clinical Sciences, Lund University, Sweden \\ ${ }^{2}$ Department of Clinical Sciences in Malmö, Social Medicine and Global Health, Lund University, Sweden \\ ${ }^{3}$ Center for Primary Health Care Research, Region Skåne and Lund University, Sweden
}

Submission: January 22, 2018; Published: February 22, 2018

*Corresponding author: Louise Bennet, Department of Clinical Sciences, Center for Primary Health Care Research, Lund University, Building 60, Floor 12, Jan Waldenströmsgata 37,Skåne University Hospital, 20502 Malmö, Sweden, Phone: +46 40391388; Fax: +46 40391370;

Email: Louise.Bennet@med.lu.se

\section{Abstract}

Background: Abdominal obesity is on the increase worldwide and ethnic minority groups are at high risk. However, studies of the underlying causes are scarce. The aims of this study were to investigate the prevalence of abdominal obesity and to identify metabolic, lifestyle and sociodemographic risk factors associated with abdominal obesity in male and female residents of Malmö, a city in southern Sweden, comparing those born in Iraq with those born in Sweden.

Method: We conducted a population-based, cross-sectional study from 2010 to 2012. Both male and female residents of Malmö, aged 30-75 years, born in Iraq $(\mathrm{n}=1387)$ or Sweden $(\mathrm{n}=749)$, underwent a physical examination. Fasting blood samples were drawn and socio-demography and lifestyle were characterized using questionnaires. Associations with abdominal obesity were assessed by logistic regression analysis.

Results: Abdominal obesity (waist circumference $\geq 80 \mathrm{~cm}$ in women and $\geq 94 \mathrm{~cm}$ in men) was highly prevalent and was most common in Iraqi-born women (Iraqi-born women $89.2 \%$ vs. Swedish women $73.1 \%$, $\mathrm{p}<0.001$, Iraqi-born men $70.2 \%$ vs. Swedish men $63.6 \%$, $\mathrm{p}<0.003$ ). Furthermore, family history of diabetes was more prevalent in participants born in Iraq than those born in Sweden $(53.6 \%$ vs. $28.5 \%$, p $<0.001)$. Based on the total study population, female gender, Middle Eastern background, family history of diabetes and depression conveyed higher odds of abdominal obesity. Family history of diabetes and Middle Eastern origin conveyed higher odds of abdominal obesity in females than in males $\left(\mathrm{P}_{\text {interaction: Female gender*Family history }}=0.023 ; \mathrm{P}_{\text {interaction: Female gender*Middle Eastern origin }}=0.011\right)$.

Conclusion: Abdominal obesity is highly prevalent irrespective of Middle Eastern or Caucasian background but most prevalent in Iraqi-born women. Our findings suggest that factors related to heritage such as genetics and traditional lifestyles, influence excess risk in Middle Eastern females in particular, which should be taken into consideration when planning preventive actions.

Keywords: Abdominal obesity; Migration; Middle East; Family history of diabetes; Gender

Abbreviations: BMI: Body Mass Index; CVD: Cardiovascular Disease; FPG: Fasting Plasma Glucose; HAD scale: Hospital Anxiety and Depression Scale; IDF: International Diabetes Federation; OGTT: Oral Glucose Tolerance Test; PA: Physical Activity; The MEDIM study: The Impact of Migration and Ethnicity on Diabetes in Malmö; T2D: Type 2 Diabetes; WHO: World Health Organization

\section{Introduction}

The worldwide prevalence of obesity has more than doubled since 1980 and overweight/obesity is the fifth leading cause of global deaths [1]. Obesity thus represents a rapidly growing threat to the health of populations in an increasing number of countries [1]. In a World Health Organization (WHO) report it was suggested that abdominal fat deposition measured by waist circumference, was a better predictor for metabolic complications such as the metabolic syndrome, cardiovascular 
disease (CVD) and type 2 diabetes (T2D), than obesity measured by body mass index (BMI) [1].

Once considered mainly an issue for high-income countries, overweight and obesity are now an increasing problem also in low- and middle-income countries, particularly in urban settings [2]. Studies from the US have shown that the prevalence of hypertension, physical inactivity, diabetes, as well as overweight, are especially high in certain populations, such as ethnic minority groups, immigrants and groups with low socioeconomic status $[3,4]$.

The largest immigrant group in Malmö and the second largest immigrant group in Sweden is represented by residents born in Iraq, a group at high risk for T2D and overweight [5]. The prevalence of T2D in immigrants from the Middle East is estimated to be twice as high as in native Swedes and the high risk is estimated to be related to obesity $[6,7]$. Thus, in order to prevent and reduce the risk of T2D in this immigrant group, studies need to identify the risk factors that contribute to abdominal obesity. The aim of this study was to measure and compare the prevalence of abdominal obesity in male and female residents of Malmö, born either in Sweden or in Iraq. A further aim was to study lifestyle, metabolic factors, psychosocial factors and socioeconomic status in association with abdominal obesity, comparing individuals born in Iraq with those born in Sweden. This has to our knowledge not been studied previously.

\section{Methods}

Malmö, which has nearly 300000 inhabitants, is the third largest city in Sweden. In 2011 national statistics reported that $32 \%$ of Malmö's population was born abroad [8]. The Iraqi immigrant group, with 9000 inhabitants is the largest one, of which the majority (5000) are between 30 and 75 years of age [8]. Between 2010 and 2012, a random sample of citizens of Malmö, born in Iraq or Sweden were selected from the census register and invited by mail and phone to participate in the MEDIM study (the impact of Migration and Ethnicity on Diabetes in Malmö). All participants, born in Sweden as well as those born in Iraq were citizens of Sweden at the time of the study. Individuals who were immobile or those with severe mental or physical illness were excluded. In total there were 2136 individuals (1387 Iraqis and 749 Swedes) who met the inclusions criteria for the study.

\section{Physical examination}

Specially trained nurses conducted a standard physical examination involving measurement of blood pressure, weight, height, waist and hip circumference, as well as the collection of blood samples and the performance of an Oral Glucose Tolerance Test (OGTT) [5].

Blood pressure was measured after five minutes' rest, in the supine position with the arm at heart level. Two measurements were taken one minute apart and the mean was calculated. The diagnosis of hypertension was based on systolic mean blood pressure of $\geq 140 \mathrm{~mm} \mathrm{Hg}$ and/or a diastolic mean blood pressure of $\geq 90 \mathrm{~mm} \mathrm{Hg}$ at the investigation, or a previous diagnosis of hypertension made by a physician [3]. Body height was measured to the nearest $\mathrm{cm}$ and body weight to the nearest $\mathrm{kg}$ in subjects wearing light clothes and without shoes and light clothing. Waist circumference was measured to the nearest $\mathrm{cm}$ in a standing position after a gentle expiration. A tape measure was placed around the bare midriff of each participant and the waist circumference measured midway between the lower border of the rib cage and the superior border of the iliac crest [4].

BMI $\left(\mathrm{kg} / \mathrm{m}^{2}\right)$ was calculated as weight $(\mathrm{kg})$ divided by height (m) squared [4]. Abdominal obesitywas considered in accordance with the WHO criteria and International Diabetes Federation (IDF), which are based on an increased risk for metabolic complications in European and Middle Eastern populations at waist circumference of $\geq 94 \mathrm{~cm}$ in men and $\geq 80$ $\mathrm{cm}$ in women $[1,9]$.

\section{Blood samples}

Blood samples were collected in the morning following a 10hour fast. All blood samples were analysed continuously during the study. Cholesterol and triglycerides in serum were analysed using enzymatic methods (Bayer Diagnostics) [10]. HDLcholesterol in serum was measured enzymatically after isolation of LDL and VLDL (Boehringer Mannheim GmbH, Germany) and LDL-cholesterol was estimated using Friedewald's method [11].

\section{Questionnaires}

Arabic and Swedish speaking nurses collected information on lifestyle habits, sociodemography, previous diagnosis of diabetes, hypertension, present medication and family history of diabetes (in biological parents and/or siblings) using structured questionnaires in both Arabic and Swedish. Two independent professional translators with Arabic as their native language translated and back-translated all questionnaires [5].

Diagnosis of diabetes was confirmed by one of the following; use of oral hypoglycemic drugs and/or insulin, Fasting Plasma Glucose (FPG) of $\geq 7 \mathrm{mmol} / \mathrm{l}$ and/or 2 -h plasma glucose level $\geq 11.1 \mathrm{mmol} / \mathrm{l}$. In case of one abnormal value, OGTT was repeated within two weeks following the same fasting procedures as used earlier. Two values exceeding the normal range were required for diagnosis of diabetes. Participants with previously known diabetes mellitus (confirmed by use of oral hypoglycaemic drugs and/or insulin or FPG of $\geq 7 \mathrm{mmol} / \mathrm{l}$ ) did not undergo OGTT [12]. Family history of diabetes was considered in the presence of diabetes in biological parents, siblings and/or children.

Moderate to severe depression: The HAD questionnaire (Hospital Anxiety and depression scale) is a 14 item scale assessing a limited set of symptoms where seven relate to anxiety and seven relate to depression. Each item on the questionnaire is scored from $0-3$. Moderate to severe depression was indicated by $>10$ points on the HAD scale [13]. 


\section{Current Research in Diabetes \& Obesity Journal}

Smoking habits: Never-smokers and individuals that had stopped smoking more than six months previously were considered non-smokers. Others were considered active smokers [14].

Alcohol consumption: All participants who consumed alcohol, regardless of quantities and frequency of drinking, were considered alcohol consumers.

Food habits were studied using questions developed by The National Board of Health and Welfare: Fish < 1/week: fish consumption less than once a week; Vegetables/fruit <1/day: intake of fruit and/or vegetables less than on a daily basis; Soda>1 week: intake of soda more than once a week; Sweets etc. $>1$ /week: intake of sweets, desserts, pastry etc. more than once a week [15].

Hours physically active/week: Physical activity (PA) was measured using questions developed by The National Board of Health and Welfare [15]. The number of minutes per week spent on non-strenuous PA (e.g., walking, cycling, or gardening), and on strenuous PA (e.g., jogging, swimming, basketball, or football), respectively, were estimated by the participants. Time conducting strenuous PA was multiplied by two and then added to time spent doing non-strenuous PA [15]. Total minutes per week were transformed to hours per week.

Economic difficulties: Difficulties in paying for food, rent or bills on one or several occasions during the last 12 months [8]. Education level was categorized as having taken high school exam or less $(<\mathrm{HS})$.

\section{Statistical Analysis}

Statistical analyses were performed using IBM SPSS 21.0 for Windows XP. Differences in means between groups were analysed using general linear models (for continuous variables) adjusted for age, while differences in proportions between groups were studied using logistic regression adjusting for age. In addition, differences in systolic and diastolic blood pressures were adjusted for anti-hypertensive medications including diuretics, ACE inhibitors, angiotensin II receptor blockers, betablockers and calcium-channel blockers. Similarly, differences in blood lipid levels (total cholesterol, HDL, LDL, triglycerides) were in addition adjusted for lipid lowering drugs. HbA1C levels were also adjusted for anti-diabetic drugs (i.e. insulin and oral hypoglycemic drugs). All tests were two-sided and p-values $<0.05$ were considered statistically significant (Table 1).

Table 1: Characteristics of women and men, with and without abdominal obesity in participants born in Iraq and Sweden.

\begin{tabular}{|c|c|c|c|c|c|c|c|c|c|c|c|c|}
\hline \multirow[t]{3}{*}{ Variables } & \multicolumn{6}{|c|}{ Women $(\mathrm{N}=928)$} & \multicolumn{5}{|c|}{ Men $(\mathrm{N}=1208)$} & \\
\hline & \multicolumn{3}{|c|}{ Born in Iraq(N=575) } & \multicolumn{3}{|c|}{ Born in Sweden $(\mathrm{N}=353)$} & \multicolumn{3}{|c|}{ Born in Iraq $(\mathrm{N}=812)$} & \multicolumn{3}{|c|}{ Born in Sweden $(N=396)$} \\
\hline & $\begin{array}{c}\text { Normal } \\
\text { waist } \\
+ \text { circum* }^{*} \\
\mathrm{~N}=62(10.6)\end{array}$ & $\begin{array}{c}\text { Abdominal } \\
\text { obesity++ } \\
\mathrm{N}=513 \\
(89.2)\end{array}$ & $\mathbf{P}$ & $\begin{array}{c}\text { Normal } \\
\text { waist } \\
\text { +circum* } \\
\mathrm{N}=95(26.9)\end{array}$ & $\begin{array}{c}\text { Abdominal } \\
\text { obesity++ } \\
\mathrm{N}=258 \\
(73.1)\end{array}$ & $\mathbf{P}$ & $\begin{array}{c}\text { Normal } \\
\text { swaist } \\
+ \text { circum* } \\
\mathrm{N}=242 \\
(29.8)\end{array}$ & $\begin{array}{c}\text { Abdominal } \\
\text { obesity++ } \\
\mathrm{N}=570 \\
(70.2)\end{array}$ & $\mathbf{P}$ & $\begin{array}{c}\begin{array}{c}\text { Normal } \\
\text { waist } \\
\text { +circum* }\end{array} \\
\mathrm{N}=144 \\
(36.4)\end{array}$ & $\begin{array}{c}\text { Abdominal } \\
\text { obesity++ } \\
\mathrm{N}=252 \\
(63.6)\end{array}$ & $\mathbf{P}$ \\
\hline Age (years) & $\begin{array}{l}41.2 \\
(8.4) \\
\end{array}$ & $\begin{array}{l}45.4 \\
(9.1) \\
\end{array}$ & 0.001 & $\begin{array}{c}46.8 \\
(11.8) \\
\end{array}$ & $\begin{array}{c}50.5 \\
(10.8) \\
\end{array}$ & 0.006 & $\begin{array}{l}45.4 \\
(9.7)\end{array}$ & $\begin{array}{l}47.7 \\
(9.7)\end{array}$ & 0.002 & $\begin{array}{c}45.3 \\
(10.3)\end{array}$ & $\begin{array}{c}51.9 \\
(11.0)\end{array}$ & $\begin{array}{c}< \\
0.001\end{array}$ \\
\hline $\begin{array}{c}\text { SBP, } \\
\text { mmHga }\end{array}$ & $\begin{array}{c}116 \\
(11.9)\end{array}$ & $\begin{array}{c}126.1 \\
(17.34)\end{array}$ & 0.003 & $\begin{array}{c}123 \\
(18.8)\end{array}$ & $\begin{array}{l}135.8 \\
(21.8)\end{array}$ & $\begin{array}{c}< \\
0.001\end{array}$ & $\begin{array}{c}127 \\
(13.8)\end{array}$ & $\begin{array}{l}134.2 \\
(16.1)\end{array}$ & $\begin{array}{c}< \\
0.001\end{array}$ & $\begin{array}{c}132 \\
(15.2)\end{array}$ & $\begin{array}{l}142.2 \\
(17.6)\end{array}$ & $\begin{array}{c}< \\
0.001\end{array}$ \\
\hline $\begin{array}{c}\text { DBP, } \\
\text { mmHga }\end{array}$ & $\begin{array}{c}72 \\
(8.4)\end{array}$ & $\begin{array}{c}76.2 \\
(10.18)\end{array}$ & 0.020 & $\begin{array}{c}74 \\
(9.7)\end{array}$ & $\begin{array}{c}81.8 \\
(11.7)\end{array}$ & $\begin{array}{c}< \\
0.001\end{array}$ & $\begin{array}{c}76 \\
(9.1)\end{array}$ & $\begin{array}{c}81.0 \\
(10.4)\end{array}$ & $\begin{array}{c}< \\
0.001\end{array}$ & $\begin{array}{c}78 \\
(10.3)\end{array}$ & $\begin{array}{l}84.9 \\
(11)\end{array}$ & $\begin{array}{c}< \\
0.001\end{array}$ \\
\hline $\begin{array}{c}\text { Cholesterol, } \\
\text { mmol/Lb }\end{array}$ & $\begin{array}{c}4.4 \\
(0.9)\end{array}$ & $\begin{array}{c}4.8 \\
(0.9)\end{array}$ & 0.090 & $\begin{array}{c}5.1 \\
(0.9)\end{array}$ & $\begin{array}{c}5.3 \\
(1.01) \\
\end{array}$ & 0.235 & $\begin{array}{c}4.9 \\
(0.9)\end{array}$ & $\begin{array}{c}5.0 \\
(1.03)\end{array}$ & 0.029 & $\begin{array}{c}5.1 \\
(1.0)\end{array}$ & $\begin{array}{c}5.3 \\
(1.1) \\
\end{array}$ & 0.021 \\
\hline $\begin{array}{c}\mathrm{p}-\mathrm{LDL} \\
\mathrm{mmol} / \mathrm{Lb}\end{array}$ & $\begin{array}{c}2.7 \\
(0.7)\end{array}$ & $\begin{array}{c}3.1 \\
(0.83)\end{array}$ & 0.011 & $\begin{array}{c}3.0 \\
(0.7)\end{array}$ & $\begin{array}{c}3.3 \\
(0.9)\end{array}$ & 0.005 & $\begin{array}{c}3.2 \\
(0.8)\end{array}$ & $\begin{array}{c}3.3 \\
(0.9)\end{array}$ & 0.090 & $\begin{array}{c}3.2 \\
(0.9)\end{array}$ & $\begin{array}{c}3.5 \\
(1.0)\end{array}$ & 0.002 \\
\hline $\begin{array}{c}\mathrm{p}-\mathrm{HDL}, \\
\mathrm{mmol} / \mathrm{Lb}\end{array}$ & $\begin{array}{c}1.5 \\
(0.4)\end{array}$ & $1.3(0.3)$ & $\begin{array}{c}< \\
0.001\end{array}$ & $1.8(0.5)$ & $1.5(0.4)$ & $\begin{array}{c}< \\
0.001\end{array}$ & $1.2(0.3)$ & $1.1(0.28)$ & $\begin{array}{c}< \\
0.001\end{array}$ & $\begin{array}{c}1.5 \\
(0.4)\end{array}$ & $\begin{array}{c}1.2 \\
(0.4)\end{array}$ & $\begin{array}{c}< \\
0.001\end{array}$ \\
\hline $\begin{array}{c}\mathrm{p}-\mathrm{TG}, \\
\mathrm{mmol} / \mathrm{Lb}\end{array}$ & $\begin{array}{c}0.9 \\
(0.4)\end{array}$ & $\begin{array}{c}1.4 \\
(0.8)\end{array}$ & $\begin{array}{c}< \\
0.001\end{array}$ & $\begin{array}{c}0.8 \\
(0.3)\end{array}$ & $\begin{array}{c}1.2 \\
(0.6)\end{array}$ & $\begin{array}{c}< \\
0.001\end{array}$ & $\begin{array}{c}1.5 \\
(0.9)\end{array}$ & $\begin{array}{c}1.9 \\
(1.58)\end{array}$ & $\begin{array}{c}< \\
0.001\end{array}$ & $\begin{array}{c}1.1 \\
(0.7)\end{array}$ & $\begin{array}{c}1.6 \\
(1.0)\end{array}$ & $\begin{array}{c}< \\
0.001\end{array}$ \\
\hline $\begin{array}{c}\mathrm{HbA1c} \\
\mathrm{mmol} / \mathrm{molc}\end{array}$ & $\begin{array}{l}34.0 \\
(7.6)\end{array}$ & $\begin{array}{c}37.0 \\
(9.06)\end{array}$ & 0.054 & $\begin{array}{l}33.9 \\
(4.1)\end{array}$ & $\begin{array}{l}36.6 \\
(8.6)\end{array}$ & 0.082 & $\begin{array}{l}36.4 \\
(8.5)\end{array}$ & $\begin{array}{c}40.0 \\
(11.2)\end{array}$ & 0.013 & $\begin{array}{l}34.5 \\
(6.4)\end{array}$ & $\begin{array}{l}38.2 \\
(9.7)\end{array}$ & 0.004 \\
\hline $\begin{array}{l}\text { Family } \\
\text { history of } \\
\text { diabetes, } \\
\mathrm{n}(\%)\end{array}$ & $\begin{array}{c}23 \\
(38.3)\end{array}$ & $\begin{array}{c}292 \\
(57.9)\end{array}$ & 0.018 & $\begin{array}{c}18 \\
(19.4)\end{array}$ & $\begin{array}{c}90 \\
(35.9)\end{array}$ & 0.007 & $\begin{array}{c}108 \\
(47.4)\end{array}$ & $\begin{array}{c}293 \\
(53.7)\end{array}$ & 0.138 & $\begin{array}{c}30 \\
(21.4)\end{array}$ & $\begin{array}{c}68 \\
(27.9)\end{array}$ & 0.141 \\
\hline
\end{tabular}




\section{Current Research in Diabetes \& Obesity Journal}

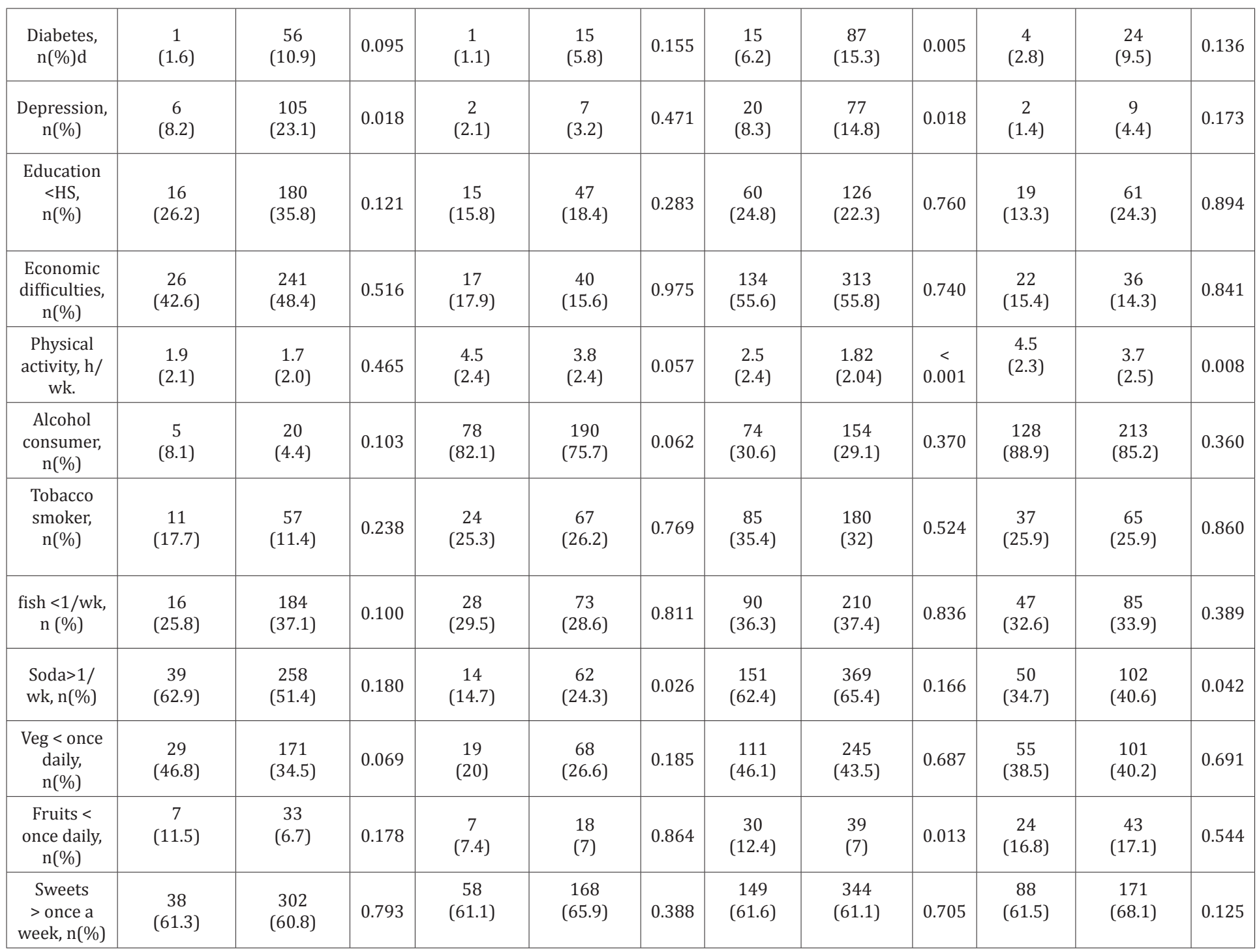

Data presented in means (standard deviation, SD) or numbers (percentages). Differences in means between groups were adjusted for age using general linear models (for continuous variables) while differences in proportions between groups) were studied using logistic regression adjusting for age

All tests were two-sided and a $p$-value of $<0.05$ was considered statistically significant.

aAdjusted for age and antihypertensive drugs (Diuretics, ACE inhibitors, Angiotensin II receptor blockers, Beta-blockers and Ca-channel blockers) , bAdjusted for age and lipid lowering drugs.

cAdjusted for age and antidiabetic drugs (Insulin and oral hypoglycemic drugs)

+ Women waist circumference $<80 \mathrm{~cm}$, men waist circumference $<94 \mathrm{~cm}$

++ Women waist circumference $\geq 80 \mathrm{~cm}$, men waist circumference $\geq 94 \mathrm{~cm}$

${ }^{*}$ Circumference

Associations with abdominal obesity were assessed using logistic regression analysis. To control for confounding variables independently associated with abdominal obesity in the univariate model (country of birth, age, gender, family history of diabetes, education, physical activity, tobacco, alcohol consumption and depression) were included in a multivariate logistic analysis (Table $2 \& 3$ ). Interactions were tested between female gender and risk factors for abdominal obesity included in the multivariate model. Associations were expressed as odds ratios (OR) with 95\% confidence intervals (CIs).Variables for which $\mathrm{p}<0.05$, were retained in the model. Multicollinearity was not considered as an issue since all VIF values were less than 2.0.

\section{Ethical considerations}

The study conforms to the principles outlined in the Declaration of Helsinki [16] and all participants gave written informed consent. The Ethics committee at Lund University approved the study (No. 2009/36 \& 2010/561). 


\section{Current Research in Diabetes \& Obesity Journal}

Table 2: Risk factors associated with abdominal obesity in the total study population.

\begin{tabular}{|c|c|c|c|c|c|c|c|c|c|}
\hline \multirow{2}{*}{ Risk Factors } & \multicolumn{2}{|c|}{$\begin{array}{c}\text { Total Study Population } \\
\text { N=2136 Univariate } \\
\text { Model }\end{array}$} & \multicolumn{2}{|c|}{$\begin{array}{c}\text { Total Study } \\
\text { Population N=1794 } \\
\text { Multivariate Model }\end{array}$} & \multicolumn{5}{|c|}{ Interaction between Female Gender and Risk Factors for } \\
Abdominal Obesity
\end{tabular}

Significant associations are bolded

Variables included in the multivariate model were country of birth, age, gender, family history of diabetes, education, physical activity, tobacco and alcohol consumption and depression. Associations with economic difficulties (i.e. difficulties in paying for food, rent or bills on one or several occasions during the last 12 months) and food habits (i.e. fish consumption less than once a week; intake of fruit and/or vegetables less than on a daily basis; intake of soda more than once a week; intake of sweets, desserts, pastry etc. more than once a week) were non-significant in the univariate model and were thus not included in the multivariate model.

Table 3: Risk factors associated with abdominal obesity. Data stratified by country of birth and gender.

\begin{tabular}{|c|c|c|c|c|c|c|c|c|c|c|c|c|}
\hline \multirow{3}{*}{$\begin{array}{l}\text { Risk Factors } \\
\text { Born in Iraq }\end{array}$} & \multicolumn{3}{|c|}{ Born in Iraq $\mathrm{N}=1172$} & \multicolumn{3}{|c|}{ Born in Sweden $\mathrm{N}=622$} & \multicolumn{3}{|c|}{$\begin{array}{c}\text { Females } \\
\mathrm{N}=785\end{array}$} & \multicolumn{3}{|c|}{$\begin{array}{c}\text { Males } \\
\mathrm{N}=1009\end{array}$} \\
\hline & \multirow{2}{*}{$\begin{array}{c}\text { OR } \\
-\end{array}$} & \multicolumn{2}{|c|}{$95 \%$ CI } & \multirow{2}{*}{$\begin{array}{c}\text { OR } \\
-\end{array}$} & \multicolumn{2}{|c|}{$95 \%$ CI } & \multirow{2}{*}{$\begin{array}{c}\text { OR } \\
1.63\end{array}$} & \multicolumn{2}{|c|}{$95 \% \mathrm{CI}$} & \multirow{2}{*}{$\begin{array}{c}\text { OR } \\
1.19\end{array}$} & \multicolumn{2}{|c|}{$95 \% \mathrm{CI}$} \\
\hline & & - & - & & - & - & & 0.89 & 2.98 & & 0.83 & 1.70 \\
\hline Age (years), per 1 SD & 1.29 & 1.10 & 1.29 & 1.69 & 1.37 & 2.10 & 1.51 & 2.22 & 1.88 & 1.37 & 1.19 & 1.58 \\
\hline Female gender & 2.94 & 2.12 & 4.16 & 1.56 & 1.09 & 2.27 & - & - & - & - & - & - \\
\hline FH of diabetes & 1.42 & 1.06 & 1.42 & 1.81 & 1.21 & 2.72 & 2.13 & 1.39 & 3.26 & 1.33 & 1.00 & 1.76 \\
\hline Education $<$ HS exam & 0.95 & 0.68 & 0.95 & 0.73 & 0.40 & 1.33 & 1.03 & 0.62 & 1.70 & 0.93 & 0.67 & 1.31 \\
\hline $\begin{array}{c}\text { Physical activity (hr/wk), } \\
\text { per } 1 \mathrm{SD}\end{array}$ & 0.78 & 0.68 & 0.78 & 0.78 & 0.66 & 0.94 & 0.91 & 0.75 & 1.10 & 0.72 & 0.63 & 0.83 \\
\hline Tobacco & 0.85 & 0.61 & 0.85 & 0.99 & 0.65 & 1.50 & 0.80 & 0.49 & 1.32 & 0.94 & 0.69 & 1.28 \\
\hline Alcohol & 0.85 & 0.59 & 0.85 & 0.66 & 0.39 & 1.11 & 0.65 & 0.36 & 1.17 & 0.80 & 0.57 & 1.12 \\
\hline Depressed & 1.82 & 1.15 & 1.82 & 2.09 & 0.67 & 6.61 & 2.33 & 1.07 & 5.09 & 1.62 & 0.97 & 2.72 \\
\hline
\end{tabular}

Significant associations are bolded.

Data were assessed using binary logistic regression analysis. Variables associated with abdominal obesity in the univariate model (country of birth, age, gender, family history of diabetes, education, physical activity, tobacco and alcohol consumption and depression) were adjusted for in the multivariate model. Associations with economic difficulties (i.e. difficulties in paying for food, rent or bills on one or several occasions during the last 12 months) and food habits (i.e. fish consumption less than once a week; intake of fruit and/or vegetables less than on a daily basis; intake of soda more than once a week; intake of sweets, desserts, pastry etc. more than once a week) were non-significant in the univariate model and were thus not included in the multivariate model. Associations are expressed as odds ratios (OR) with $95 \% \mathrm{Cl}$. 
Results

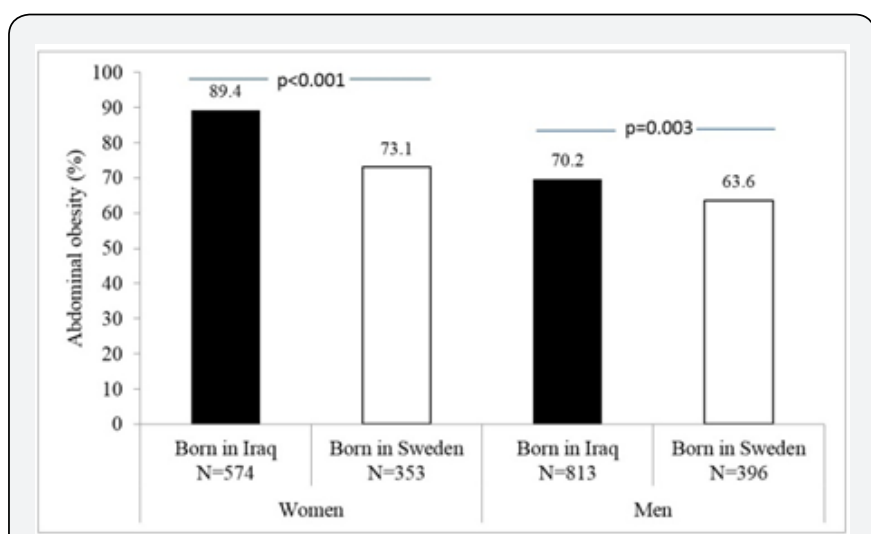

Figure 1: Prevalence of abdominal obesity in Iraqi and Swedish women and men.

Abdominal obesity was highly prevalent in both Iraqi immigrants (78.1\%) and native Swedes (68.1\%), however, significantly more so in the former $(\mathrm{p}<0.001)$. Further, abdominal obesity was most prevalent in Iraqi-born women $(89.2 \%$ vs. Swedish women $73.1 \%$, p $<0.001$ ) whereas it was least prevalent in Swedish men (63.6\% vs. Iraqi-born men 70.2\%, p=0.003, age adjusted data) (Figure 1). Mean BMI in Iraqi-born participants as compared to Swedes were higher in both women and men (women 29.7 vs $27.1 \mathrm{~kg} / \mathrm{m}^{2}$, p<0.001; men 29.0 vs. $27.4 \mathrm{~kg} /$ $\mathrm{m}^{2}, \mathrm{p}<0.001$ age adjusted data).Family history of diabetes was highly prevalent amongst the Iraqi-born participants (53.6 vs. $28.5 \%$ in Swedes, $\mathrm{p}<0.001$, age and sex adjusted data). However, in females only, the prevalence of family history of diabetes was significantly higher in those with abdominal obesity compared with those with normal waist circumference (Figure 2).

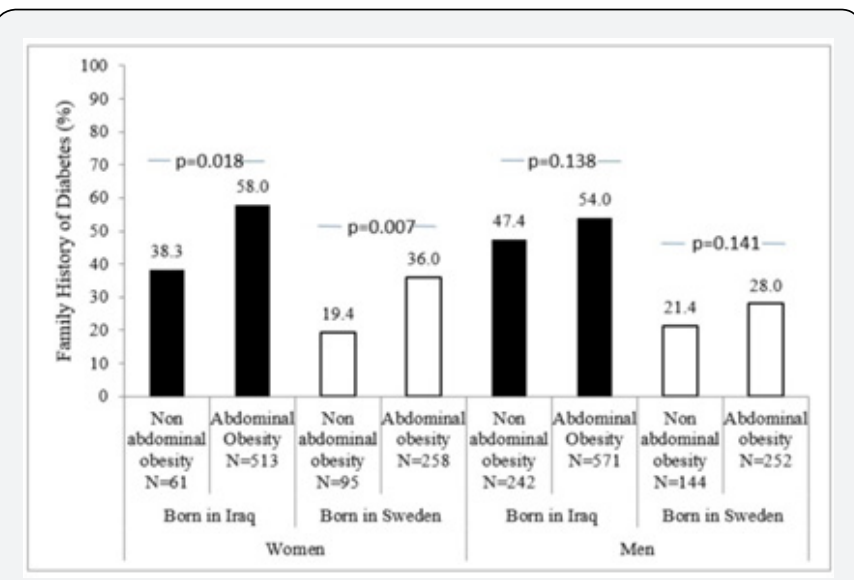

Figure 2: Prevalence of family history of diabetes in Iraqi and Swedish women and men.

Characteristics stratified by gender, ethnicity and presence of abdominal obesity are shown in Table 1. Irrespective of country of birth, women and men with abdominal obesity were older, had higher levels of triglycerides and lower levels of HDL as well as higher systolic and diastolic blood pressures as compared to women and men with normal waist circumference. Iraqi-born females with abdominal obesity didn't differ in terms of life-style related factors like physical activity level, alcohol consumption, smoking, fish intake, fruit and vegetable consumption and soda intake, compared to those without abdominal obesity. By contrast, Iraqi-born men with abdominal obesity were less physically active and ate fruits less frequently, compared to those without abdominal obesity. In the Swedish group, men with abdominal obesity were less physically active and consumed soda more frequently than their compatriots with normal waist circumference, whereas in Swedish females differences were only seen in soda consumption. Further, Iraqi-born men and women with abdominal obesity had higher prevalence of depression compared to their compatriots with normal waist circumference, no such association was seen in the Swedish group. There were no significant differences in socio-economic variables like level of education and economic difficulties in individuals with or without abdominal obesity, neither in the Swedish nor the Iraqiborn participants. Associations with abdominal obesity were assessed by univariate and multivariate analysis (Table $2 \& 3$ ). In the entire study population, older age, being born in Iraq, female gender, having a family history of diabetes and depression were independently associated with increased odds of abdominal obesity whereas more hours being physically active were associated with reduced odds of abdominal obesity. Studying interactions, we observed that gender modified the effect of country of birth (Pinteraction= 0.011 ) as well as of family history of diabetes (Pinteraction=0.023) on abdominal obesity (Table 2).Thus, in a next step the analysis was stratified according to country of birth. In that model Iraqi-born females, as compared to males, had higher odds of abdominal obesity compared to their Swedish counterparts. The data was also stratified according to gender. We also observed that family history of diabetes had higher odds of abdominal obesity in females than in males. Further, depression was associated with increased odds of abdominal obesity in participants born in Iraq as well as in females. However, we observed no interactions between gender and depression or between country of birth and depression on abdominal obesity.

\section{Discussion}

The key finding of the present study is the generally high prevalence of abdominal obesity in both populations of Middle Eastern and Caucasian origin. The prevalence was in particularly high in Iraqi-born women. Our finding of a modifying effect of gender on family history of diabetes and ethnicity with regards to abdominal obesity, suggests that family history of diabetes and Middle Eastern background contributes to a higher extent to abdominal obesity in women than in men. Altogether our data indicates that factors related to heritage such as genetics and traditional lifestyles influence abdominal risk in Middle Eastern females in particular.

\section{Abdominal obesity and Middle Eastern background}

In the present study, almost $90 \%$ of the Iraqi-born women had abdominal obesity, which is considerably higher than the 
prevalence of $40 \%$ found in a previous studyfrom Sweden of randomly sampled immigrant women from the Middle East [17]. However, in the previous study the population was younger (1865 years of age) and abdominal obesity was defined as waist circumference $\geq 88 \mathrm{cminstead}$ of $>80 \mathrm{~cm}$ as in the present study, which may explain the difference in prevalence rates. In one of the studies conducted across 14 Middle Eastern and African countries, it was found that the prevalence of abdominal obesity in the region was twice as high compared to obesity defined by BMI [18]. The prevalence of abdominal obesity in Iraqi-born women $(89.4 \%)$ compared to Swedish-born women (73.1\%) is also in consistency with another study conducted in Sweden reporting over a decimeter larger waist circumference in Iraqiborn as compared to Swedish-born women, (98 vs. $86 \mathrm{~cm}$ ) [19].

Abdominal obesity is a component of the metabolic syndrome $[1,8]$. In this study the cut-off values for abdominal obesity were derived specifically from WHO and IDF for Middle Eastern and Mediterranean populations $[1,8]$. Previous studies have shown that CVD as well as T2DM risk, worsens substantially above the cut-off values for abdominal obesity [20-23]. For instance, individuals with abdominal obesity are twice as likely to have one or more major CVD risk factors and should be supported to undergo lifestyle modification to lower the risk of CVD [22]. Abdominal obesity is also a better predictor of T2DM than BMI [23]. Additionally, from a clinical perspective, it is easier to identify risk groups using cut off values for abdominal obesity, rather than waist circumference per se, which therefore adds clinical significance to our findings. Meanwhile, it is important to explore factors that have protected over $10 \%$ of Iraqi-born females from developing abdominal obesity. Our data indicated a slightly protective effect of physical activity, tobacco and alcohol consumption in the Iraqi-born group by having lower odds of abdominal obesity. However there is a need to identify other socio-economic, lifestyle and genetic factors that might protect or predispose Iraqi-born women to abdominal obesity.

\section{Abdominal obesity and family history of diabetes}

The Botnia study conducted in Finland has reported that participants with positive first-degree family history of diabetes had a higher waist-hip ratio compared to those who had a negative family history for diabetes. Moreover, females with family history of diabetes had a higher waist-height index, another measure for abdominal obesity, compared to females who had no family history of diabetes [24]. These observations are in line with our findings that women with family history have higher odds of abdominal obesity than men with family history of diabetes (2.1 vs 1.3 ) and support the possibility of a gender dependent association between family history of diabetes and abdominal obesity [25].

Our data suggests that females with Middle Eastern background and family history of diabetes might benefit from surveillance of the metabolic profile including waist circumference as well as from advice on lifestyle modification such as changes in diet and physical activity levels.

\section{Depression and abdominal obesity}

Depression was significantly associated with abdominal obesity in the total study population. When stratifying the data according to gender we also observed that the associations remained in women and in participants born in Iraq, however we could not find that gender or country of birth modified the effect of depression. Our findings are in consistency with the literature, reporting a positive association between depression and abdominal obesity more consistently for women, whereas in menthe association is either absent, weak or in some cases even inverse [26]. Women with depressive symptoms were in another study reported to have larger waist circumference compared to non-depressed women even after multiple adjustments [27].

In addition, the association between depression and abdominal obesity was manifest only in the Iraqi immigrants. In one of the few studies on this topic, an interaction was reported between post-traumatic stress disorder and race with regard to abdominal obesity; however, no such interaction was seen between major depressive disorder and race [28]. This association between ethnicity, depression and obesity therefore, needs to be explored further.

\section{Strengths and Limitations}

Strengths of the present study include the large sample size and the random recruitment of participants. The participation rate was relatively high, especially in the Iraqi group. The thorough information on medical history and detailed data on lifestyle habits (including food intake and physical activity) and socioeconomic situation are other strengths.

Although BMI is the most commonly used method for measuring obesity in clinical practice, intra-abdominal adipose tissue estimated by waist circumference has been more strongly linked to T2D and CVD risk [29,30]. In our study, thresholds recommended by the WHO and the International Diabetes Federation (IDF) in populations with different ethnic background $[1,9]$ were thus used to classify abdominal obesity. Repeating the analysis with waist circumference as the outcome variable, did not change the main findings of the study that gender modified the effect of family history and Middle Eastern background on larger waist circumference (data not shown). Although all data were adjusted for age and gender, the skewed gender recruitment with a higher participation rate of Iraqi-born men than women may still not be adequately compensated for, which is a potential weakness. Furthermore, the cross-sectional design does not allow for conclusions with regard to causality.

\section{Conclusion}

We conclude that abdominal obesity is highly prevalent in immigrants from the Middle East especially in Iraqi-born women. 
Our findings suggest that family history of diabetes and Middle Eastern background contributes to a higher extent to abdominal obesity in women than in men. We conclude that factors related to heritage, such as genetics and traditional lifestyles, influence excess risk in Middle Eastern females in particular, which should be taken into consideration when planning preventive actions against obesity and type 2 diabetes].

\section{Conflict of Interest}

No potential conflict of interest relevant to this study was reported.

\section{Author Contributions}

F.S. analysed and interpreted the data and co-wrote the manuscript; H.I. participated in writing the manuscript, analysing and interpreting the data; C.A.L. assisted with interpretation of the data, discussions and in writing the manuscript and L.B. designed the study, conceived and analyzed the data and cowrote the manuscript. All authors have revised/edited the article critically and have approved the final version of the manuscript.

\section{Acknowledgement}

We are indebted to: Marita Olsson, Katarina Balcker Lundgren, Enas Basheer El-Soussi and Asma Saleh for their excellent work in examining the participants and collecting data and Patrick Reilly, Center for Primary Health Care Research for his skillful advice and for proof reading the manuscript.

\section{Funding}

This study was funded by grants from Lund University (ALF grant Skane 20101641, 20101837and 162641), Region Skåne (226661 and 121811), The Swedish Society of Medicine (SLS97081 and 176831) and the Crafoord Foundation (20110719).

\section{References}

1. (2014) Obesity: preventing and managing the global epidemic. Report of a WHO consultation.

2. http://www.who.int/mediacentre/factsheets/fs311/en/accessed Jan2014.

3. (1999) 1999 World Health Organization-International Society of Hypertension Guidelines for the Management of Hypertension. Guidelines Subcommittee. J Hypertens (2): 151-183.

4. (1998) Clinical guidelines on the identification, evaluation, and treatment of overweight and obesity in adults--The Evidence Report. National Institutes of Health. Obesity research 6(suppl 2): 51S-209S.

5. Bennet L, Johansson SE, Agardh CD, Groop L, Sundquist J, et al. (2011) High prevalence of type 2 diabetes in Iraqi and Swedish residents in a deprived Swedish neighbourhood--a population based study. BMC public health 11: 303.

6. Wandell PE, Wajngot A, de Faire U, Hellenius ML (2007) Increased prevalence of diabetes among immigrants from non-European countries in 60-year-old men and women in Sweden. Diabetes Metab 33(1): 30-36.

7. Carlsson AC, Wandell PE, Hedlund E, Walldius G, Nordqvist T, et al.
(2013) Country of birth-specific and gender differences in prevalence of diabetes in Sweden. Diabetes Res Clin Pract 100(3): 404-408.

8. (2012) Statistics Sweden.

9. Alberti KG, Eckel RH, Grundy SM, Zimmet PZ, Cleeman JI, et al. (2009) Harmonizing the metabolic syndrome: a joint interim statement of the International Diabetes Federation Task Force on Epidemiology and Prevention; National Heart, Lung, and Blood Institute; American Heart Association; World Heart Federation; International Atherosclerosis Society; and International Association for the Study of Obesity. Circulation 120(16): 1640-1645.

10. Allain CC, Poon LS, Chan CS, Richmond W, Fu PC (1974) Enzymatic determination of total serum cholesterol. Clin Chem 20(4): 470-475.

11. Friedewald WT, Levy RI, Fredrickson DS (1972) Estimation of the concentration of low-density lipoprotein cholesterol in plasma, without use of the preparative ultracentrifuge. Clin Chem 18(6): 499502 .

12. Bennet L, Groop L, Franks PW (2014) Ethnic differences in the contribution of insulin action and secretion to type 2 diabetes in immigrants from the Middle East compared to native Swedes. Diabetes Res Clin Pract 105(1): 79-87.

13. Bjelland I, Dahl AA, Haug TT, Neckelmann D (2002) The validity of the Hospital Anxiety and Depression Scale. An updated literature review. J Psychosom Res 52(2): 69-77.

14. Bakkevig O, Steine S, von Hafenbradl K, Laerum E (2000) Smoking cessation. A comparative, randomised study between management in general practice and the behavioural programme Smok Enders. Scand J Prim Health Care 18(4): 247-251.

15. Nationella riktlinjer för sjukdomsförebyggande behandling.

16. Declaration of Helsinki-Ethical principles of medical research involving human subjects.

17. Faskunger J, Eriksson U, Johansson SE, Sundquist K, Sundquist J (2009) Risk of obesity in immigrants compared with Swedes in two deprived neighbourhoods. BMC public health 9: 304.

18. Alsheikh Ali AA, Omar MI, Raal FJ, Rashed W, Hamoui O, et al. (2014) Cardiovascular risk factor burden in Africa and the Middle East: The Africa Middle East Cardiovascular Epidemiological (ACE) Study. PLoS One 9(8): e102830.

19. Carlsson AC, Wandell P, Riserus U, Arnlov J, Borne Y, et al. (2014) Differences in anthropometric measures in immigrants and Swedishborn individuals: results from two community-based cohort studies. Prev Med 69: 151-156.

20. Du T, Sun X, Yin P, Yuan G, Zhang M, et al (2014) Secular trends in the prevalence of low risk factor burden for cardiovascular disease according to obesity status among Chinese adults, 1993-2009. BMC public health 14: 961.

21. Matsha TE, Hassan MS, Hon GM, Soita DJ, Kengne AP, et al. (2013) Derivation and validation of a waist circumference optimal cutoff for diagnosing metabolic syndrome in a South African mixed ancestry population. Int J Cardiol 168(3): 2954-2955.

22. Han TS, van Leer EM, Seidell JC, Lean ME (1995) Waist circumference action levels in the identification of cardiovascular risk factors: prevalence study in a random sample. BMJ 311(7017): 1401-1405.

23. Paek KW, Chun KH (2010) Sex difference of type 2 diabetes affected by abdominal obesity versus overall obesity. Yonsei Med J 51(6): 850-856.

24. Groop L, Forsblom C, Lehtovirta M, Tuomi T, Karanko S, et al. (1996) Metabolic consequences of a family history of NIDDM (the Botnia study): evidence for sex-specific parental effects. Diabetes 45(11): 1585-1593. 


\section{Current Research in Diabetes \& Obesity Journal}

25. Regitz Zagrosek V, Lehmkuhl E, Weickert MO (2006) Gender differences in the metabolic syndrome and their role for cardiovascular disease. Clin Res Cardiol 95(3): 136-147.

26. Carpenter KM, Hasin DS, Allison DB, Faith M (2000) Relationships between obesity and DSM-IV major depressive disorder, suicide ideation, and suicide attempts: results from a general population study. Am J Public Health 90(2): 251-257.

27. Muhtz C, Zyriax BC, Klahn T, Windler E, Otte C (2009) Depressive symptoms and metabolic risk: effects of cortisol and gender Psychoneuroendocrinology 34(7): 1004-1011.
28. Dedert EA, Harper LA, Calhoun PS, Dennis MF, Beckham JC (2013) The impact of race on metabolic disease risk factors in women with and without posttraumatic stress disorder. J Clin Psychol Med Settings 20(1): 46-55.

29. Shiina Y, HommaY (2013) Relationships between the visceral fat area on CT and coronary risk factor markers. Intern Med 52(16): 17751780 .

30. Pinter Z, Molnar A, Szasz A, Kiss G, Orban K, et al. (2013) Reliability of anthropometric parameters in the prediction of the visceral fat area among adult women. Anthropologischer Anzeiger 70(2): 147-164.

\section{Your next submission with Juniper Publishers will reach you the below assets}

- Quality Editorial service

- Swift Peer Review

- Reprints availability

- E-prints Service

- Manuscript Podcast for convenient understanding

- Global attainment for your research

- Manuscript accessibility in different formats

( Pdf, E-pub, Full Text, Audio)

- Unceasing customer service

Track the below URL for one-step submission https://juniperpublishers.com/online-submission.php 